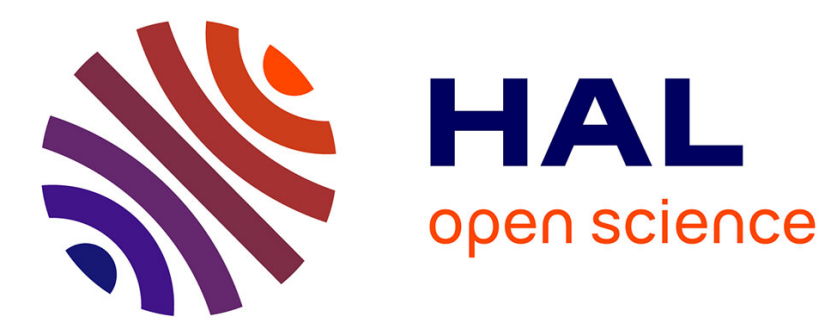

\title{
Paleoseismic History of the Dead Sea Fault Zone
}

Mustapha Meghraoui

\section{To cite this version:}

Mustapha Meghraoui. Paleoseismic History of the Dead Sea Fault Zone. Encyclopedia of Earthquake Engineering, 2015, 10.1007/978-3-642-36197-5_40-1 . hal-01264171

\section{HAL Id: hal-01264171 \\ https://hal.science/hal-01264171}

Submitted on 28 Jan 2016

HAL is a multi-disciplinary open access archive for the deposit and dissemination of scientific research documents, whether they are published or not. The documents may come from teaching and research institutions in France or abroad, or from public or private research centers.
L'archive ouverte pluridisciplinaire HAL, est destinée au dépôt et à la diffusion de documents scientifiques de niveau recherche, publiés ou non, émanant des établissements d'enseignement et de recherche français ou étrangers, des laboratoires publics ou privés. 


\title{
Paleoseismic History of the Dead Sea Fault Zone
}

\author{
Mustapha Meghraoui* \\ Institut de Physique du Globe, CNRS-UMR 7516, Ecole et Observatoire des Sciences de la Terre, Université de Strasbourg, \\ Strasbourg, France
}

\section{Synonyms}

Active faulting; Earthquake rupture; Seismicity; Seismic slip deficit; Slip rate; Trench investigations

\section{Introduction}

Major continental faults often constitute plate boundaries with transtensional and transpressional styles of active deformation. The repetition of large earthquakes with $\mathrm{Mw}>7$ along these faults is closely associated to the rate of activity between the plates and to the rupture segmentation over the late Quaternary (Sieh 1996). In the last century, large earthquakes with surface ruptures have been documented on the San Andreas fault in California, the North Anatolian fault and East Anatolian fault in Turkey, the Alpine fault in New Zealand, and the northern Tibet transcurrent faults in China. The observation, description, and measurements of coseismic surface faulting constitute the basis for the development of earthquake geology and paleoseismic investigations (Yeats et al. 1997). Nevertheless, among all continental transform systems, the Dead Sea fault (DSF, Fig. 1) is an exception because of its apparent last-century seismic quiescence and, therefore, variability of earthquake activity and faulting behavior (Fig. 2).

The existence of a dense population with small and large urban areas throughout the successive civilizations is the source for a continuous record of seismic events that favors a completed seismicity catalogue for major earthquakes along the DSF (Ambraseys and Barazangi 1989; Amiran et al. 1994; Sbeinati et al. 2005; Ambraseys 2009). The instrumental seismicity (younger than 1900 A.D.) of the continental Dead Sea fault is of a relatively low level compared to other faults, such as the nearby East Anatolian fault or North Anatolian fault. Indeed, the largest earthquake that took place in the last century is the 13 July 1927 with a local magnitude $\mathrm{M}_{\mathrm{L}}=6.2$ that caused severe damage in Jericho and Jerusalem. More recently, the Mw 7.3 Nuweiba earthquake that took place offshore and further south in the Gulf of Aqaba and northern Red Sea occurred as a reminder that large seismic events may be generated further north along the DSF. The apparent quiescence and the lack of major seismic events with $\mathrm{Mw}>6.0$ on most fault segments in the last centuries are in contradiction with the historical catalogue and related report of faulting events over the last 3,000 years or so along the continental DSF (Guidoboni et al. 1994; Ambraseys and Jackson 1998; Sbeinati et al. 2005).

The understanding of earthquake rupture parameters and pattern of surface deformation is a critical aspect for the identification of recurrent surface faulting and building of a paleoseismic history (McCalpin 1996). Models of earthquake faulting were first based on the fault segmentation with persistent structural boundaries and characteristic earthquake behavior that suggest the repetition of same size events with similar coseismic slip along strike (Sieh 1996; Wesnousky 2006). Field investigations on pre-instrumental earthquakes using tectonic geomorphology, paleoseismology and archeoseismology along the DSF benefit from the richness of the historical archives and seismicity catalogue (Agnon 2014). These field

\footnotetext{
*Email: m.meghraoui@unistra.fr
} 


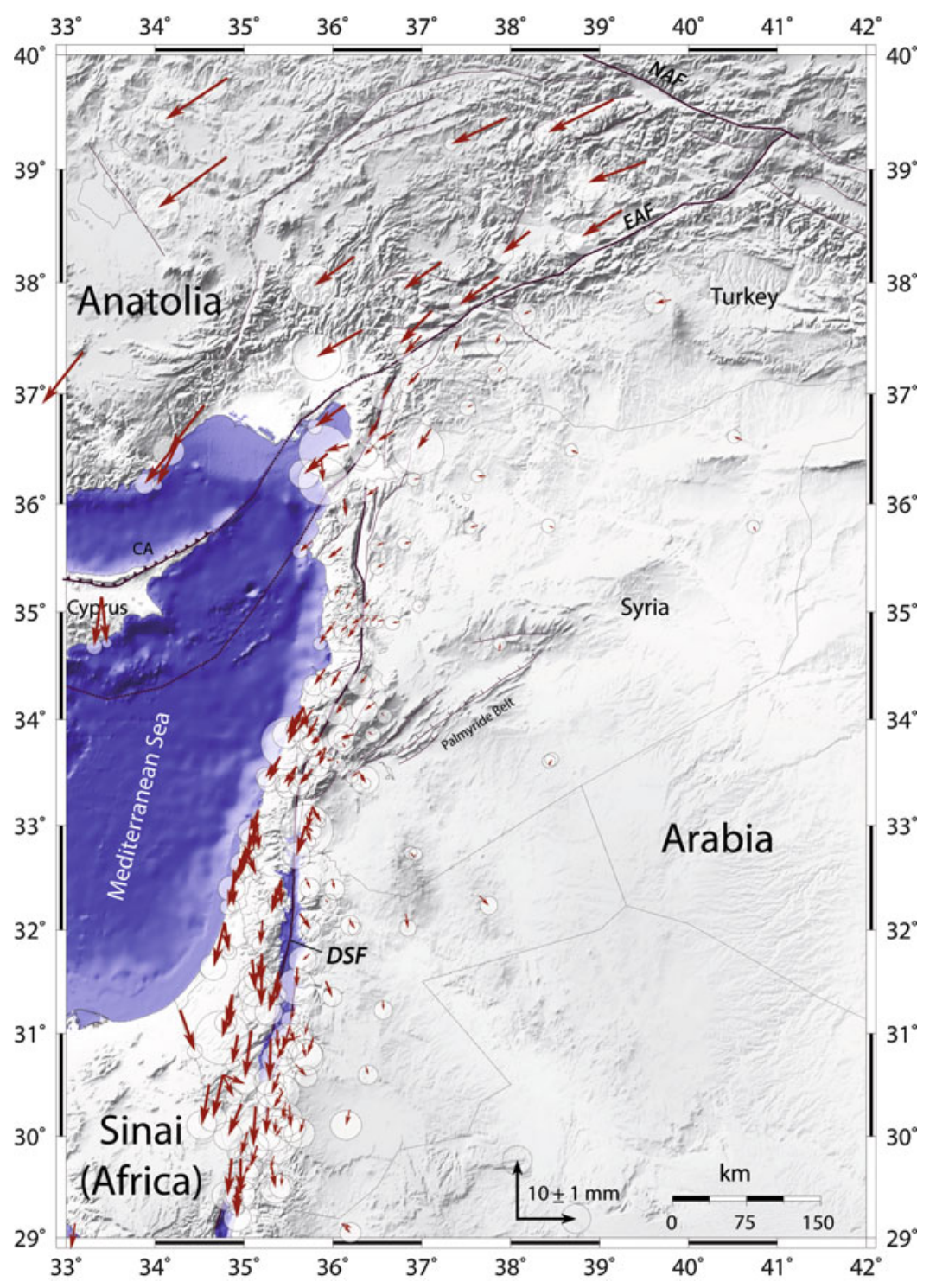

Fig. 1 Plate boundaries (thick black lines) in the eastern Mediterranean pointing out the Dead Sea fault (DSF), East Anatolian fault $(E A F)$, North Anatolian fault (NAF), and GPS data (Wdowinski et al. 2004; Reilinger et al. 2006; Gomez et al. 2007; Le Béon et al. 2008; Alchalbi et al. 2010; Al Tarazi et al. 2011; Mahmoud et al. 2013; Masson et al. 2015). The DSF is a boundary between Arabia plate to the east and the Sinai (Africa) plate to the west. GPS velocities are given with Arabia-fixed frame; fault segments and offsets are in Fig. 3. Topography and bathymetry data is from SRTM 3-second-arc and GEBCO_08 grid

approaches tracing the past surface ruptures with related coseismic slip and other fault parameters provide an estimate of seismic moment of past large earthquakes with the constraint of interseismic periods and level of seismic coupling along the DSF.

The aim of this entry is to describe the DSF as a transform plate boundary pointing out the rate of active deformation, fault segmentation, and geometrical complexities as a control of earthquake ruptures. The distribution of large historical earthquakes from a revisited seismicity catalogue using detailed macroseismic maps allows the correlation between the location of past earthquakes and fault segments. The recent results of paleoearthquake investigations (paleoseismic and archeoseismic) with a recurrence interval of large events and long-term slip rate are presented and discussed along with the identification of seismic gaps along the fault. Finally, the implications for the seismic hazard assessment are also discussed. 


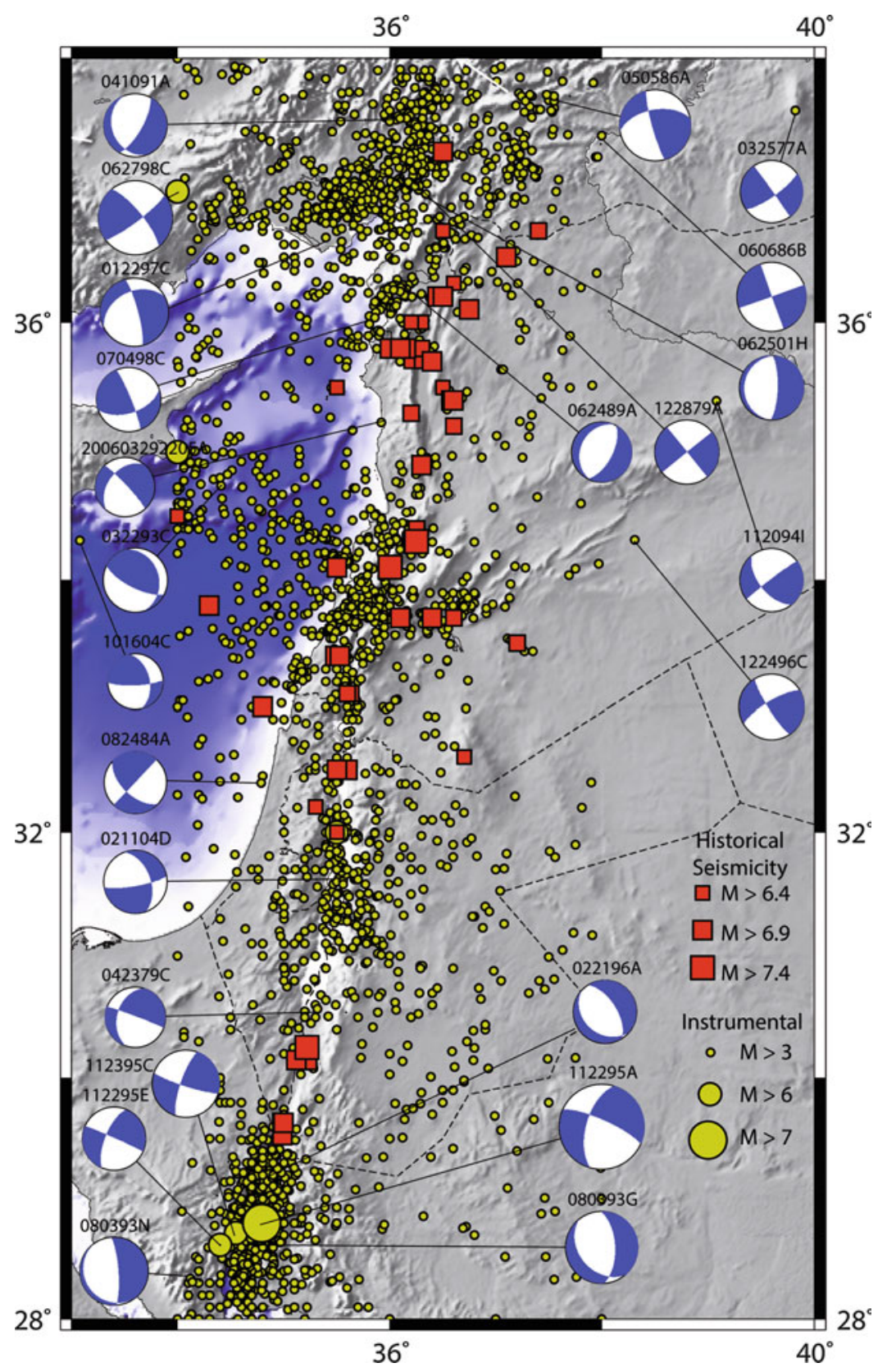

Fig. 2 Last-century instrumental seismicity (1900-2012, yellow circle) and historical seismicity (1365 B.C.-1900, red box) along the Dead Sea fault (see text for references therein). Focal mechanisms are from Harvard CMT. Note the last-century low-level background seismicity with respect to the significantly large historical earthquakes that illustrate the variability of earthquake activity and faulting behavior. Topography and bathymetry data is from GEBCO_08 grid

\section{The Dead Sea Transform: A Continental Plate Boundary}

The DSF is a north-south trending continental plate boundary and transform crustal structure that separates the Arabian plate to the east from the African-Sinai plate to the west (Fig. 1). The left-lateral 1,000-km-long fault exhibits a southern transtensional section that includes the Dead Sea until the Gulf of Aqaba, a central section characterized by the Lebanese restraining bend, and the northern section that limits to the west the Syrian coastal ranges (Garfunkel et al. 1981). The DSF results from the differential northward movement of Arabia and Africa relative to Eurasia and connects the seafloor spreading of the 


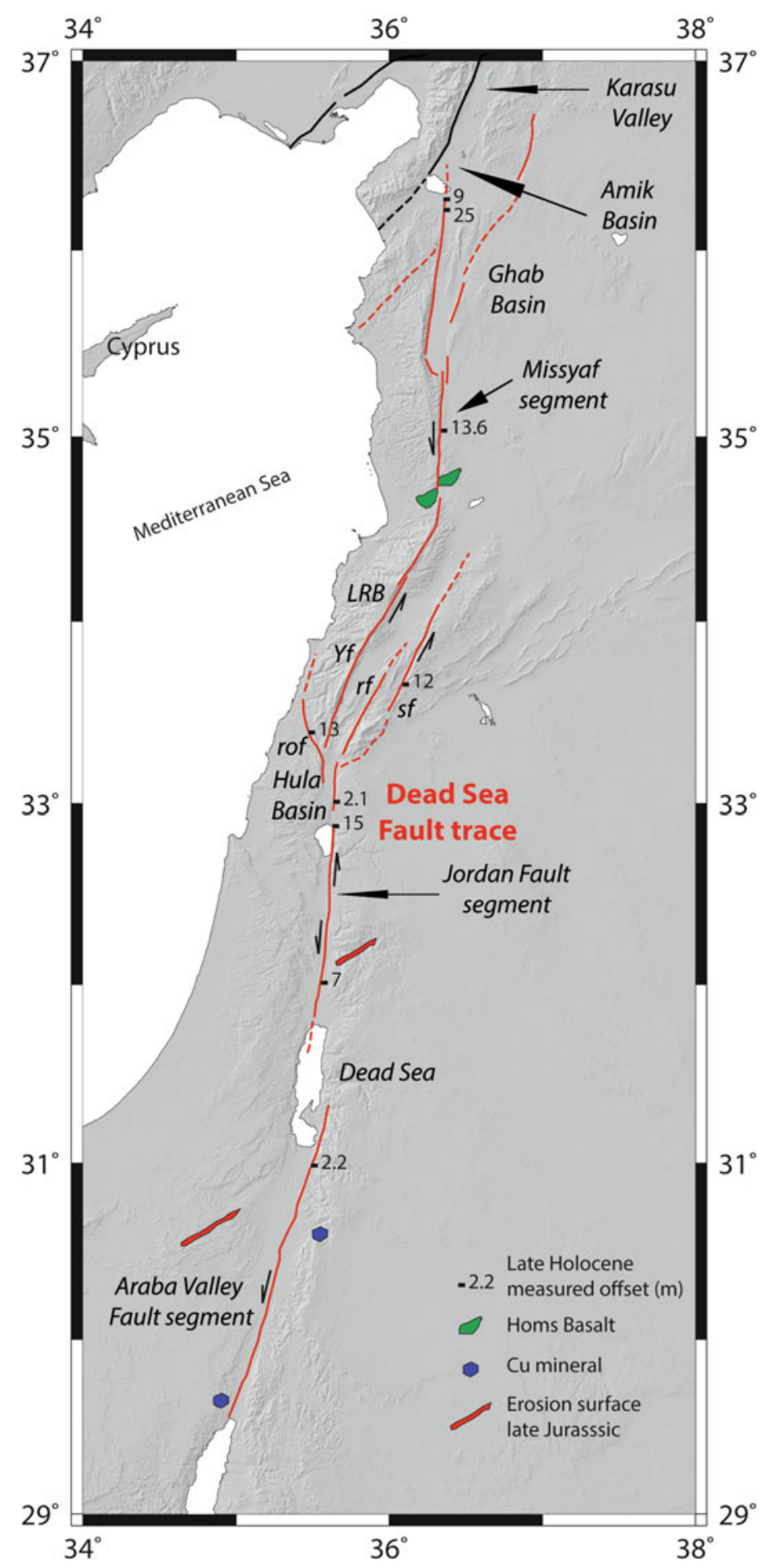

Fig. 3 Dead Sea fault trace from the detailed mapping of individual segments using aerial and satellite photographs combined with field investigations. The fault detailed mapping is from the results of the APAME Project (APAME 2007). Various late Holocene offsets from published works are indicated along with geological offsets (e.g., 107-km left-lateral offset of the erosion surface of late Jurassic units; see text for references). Topography data is from SRTM (3-arc-second)

Gulf of Aqaba - Red Sea in the south to Anatolia in the north. Indeed, both plates drift north at a rate of $18 \mathrm{~mm} /$ year for Arabia and at about $6 \mathrm{~mm} /$ year for Africa-Nubia (Reilinger et al. 2006). GPS campaigns from 1991 to 2011 on about 35 stations along all the DSF (computed for Arabia or Eurasia fixed) provide 
an average geodetic velocity field of $\sim 5 \mathrm{~mm} /$ year, $\sim 4.7 \mathrm{~mm} /$ year, and $\sim 2 \mathrm{~mm} /$ year for the south, central, and north segments, respectively (Fig. 2). It is worth to mention that GPS measurements and late Quaternary tectonic investigations across the NE trending Palmyride fold belt, a branch of the DSF in Syria, show less than $1 \mathrm{~mm} /$ year of active regional shortening along the NNW-SSE direction (Chaimov et al. 1990; Abou Romieh et al. 2009; Alchalbi et al. 2010). Dislocation models based on GPS profiles across the fault reveal an average 11-km locking depth for the elastic crustal thickness along the fault zone (Wdowinski et al. 2004; Reilinger et al. 2006; Gomez et al. 2007; Le Béon et al. 2008; Alchalbi et al. 2010; Al Tarazi et al. 2011; Mahmoud et al. 2013; Masson et al. 2015). The crustal structure depicted from deep seismic and gravity profiles, combined with the outcropping geology across the Dead Sea basin and Araba valley, reaches from west to east from 26 to $39 \mathrm{~km}$, indicating a small asymmetric topography of the Moho discontinuity (Weber et al. 2009). Focal mechanisms of earthquakes and geodetic and tectonic observations characterize the stress and strain field which is in agreement with the left-lateral strike-slip mechanism, even if locally main principal stress directions may rotate and show normal (Dead Sea) or thrust mechanisms (Hofstetter et al. 2007; Palano et al. 2013). In the northern sector of the DSF, the stress field results from the complex tectonic interaction between the Arabian, Anatolian-Eurasian, and African-Sinai plates which occurs along the Hatay triple junction (Mahmoud et al. 2013).

The onset of the fault activity is not well constrained, but the largest recorded slip on the fault and size of the Dead Sea basin $(>100 \mathrm{~km}$ in length when including the Jordan valley) provide some evidence. Leftlateral strike-slip motions are visible on all three sections, thanks to geologic and geomorphic offsets along the DSF (Fig. 3). Initially, Dubertret (1932), who adopted the continental drift theory as a possible mode for structuring the Red Sea and the surrounding areas, proposed a model whereby the "Sinai block" drifted southward for $160 \mathrm{~km}$ along the DSF. Later on, a total of 107-km slip is estimated from the offset of a Jurassic stratigraphic sequence and offset dikes dated to $20 \mathrm{Ma}$ that result in a 4-7-mm/year slip rate during 15-20 Myr along the southern section of the fault (Quennell 1958; Bartov et al. 1980; Garfunkel et al. 1981). Different authors suggest that the fault structure and left-lateral motion result from two main tectonic episodes with $65-\mathrm{km}$ slip accumulating during the Miocene and 42-km post-Miocene slip. The southern section of the plate boundary also probably functioned independently accumulating about $60 \mathrm{~km}$ of pre-Pliocene slip, and offset basalts in the northern section document the post-Miocene-early Pliocene (5-6 Ma) displacement (Chaimov et al. 1990; Brew et al. 2001). The complex structure of the Lebanese restraining bend and adjacent Palmyride fold belt may be responsible for the discrepancy in the fault offset between the northern and southern sections of the DSF. Hence, the total southern offset becomes partitioned further north into fault-parallel slip and fold-perpendicular compression (e.g., Chaimov et al. 1990). The fault geometry and left-lateral behavior govern the kinematics of all segments, with auxiliary tectonic regimes such as pull-apart basins (Dead Sea, Hula and Ghab depressions) and shortening within the LRB.

\section{A Tectonic Fault Trace with Geometrical Complexities}

The marks of Quaternary deformation are observable at all scale and on all sections along the DSF. Using the geological and geomorphological maps, the linear shape of the fault affecting late Pleistocene and Holocene deposits can be identified on Landsat, SPOT, and QuickBird satellite photographs as well as on aerial photographs.

The southernmost DSF zone crosses the western edge of the Gulf of Aqaba and extends further north for about $40 \mathrm{~km}$ crossing fluvial and alluvial terraces of Avrona Playa and the Wadi Araba Valley. Several fault branches may outcrop showing normal geometry in this area, but they may result from the slip partitioning on branches of the main DSF (Zilberman et al. 2005). To the north, except for the 


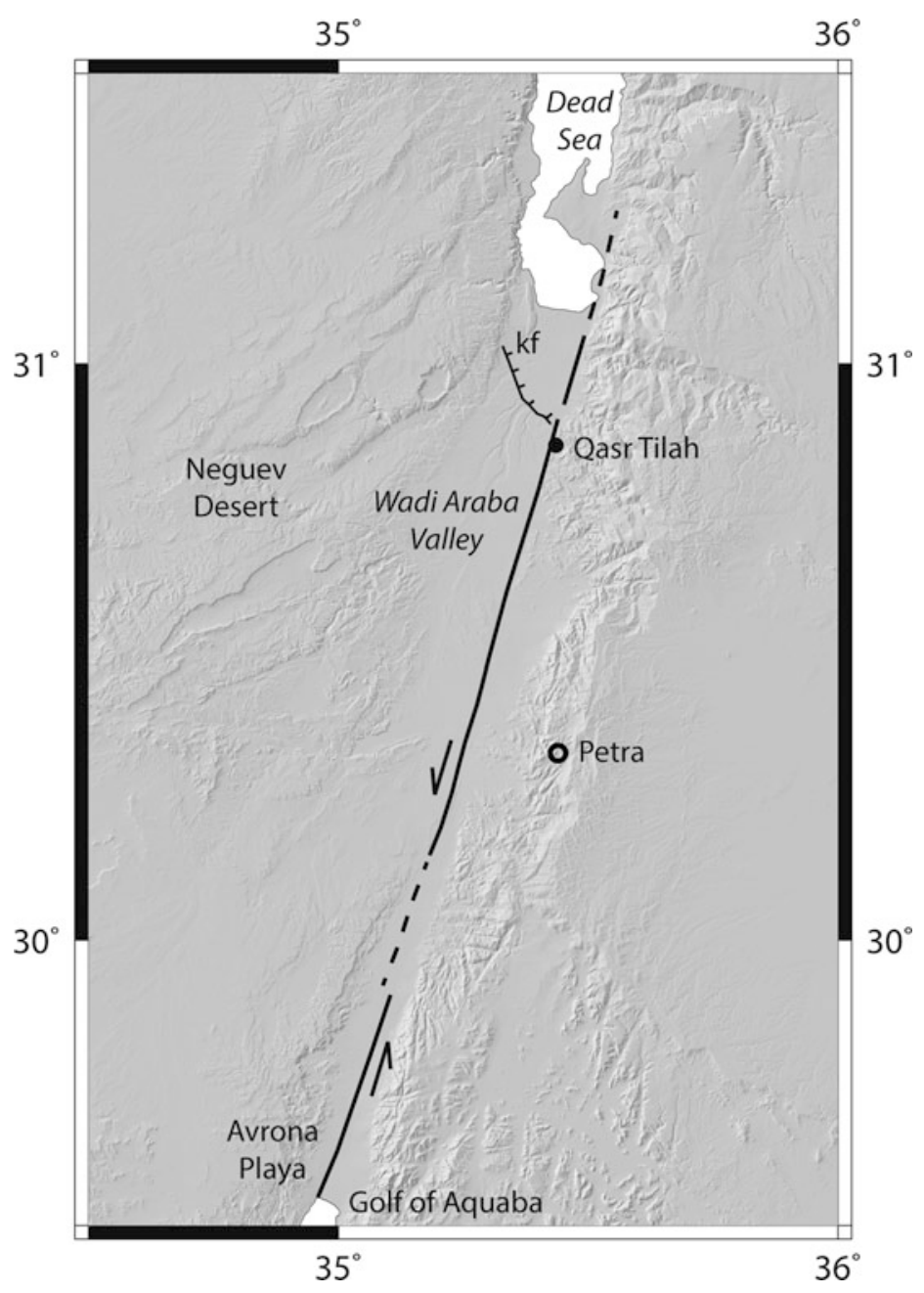

Fig. 4 The 200 -km-long Wadi Araba fault section from the eastern edge of the Dead Sea area to the Aqaba Gulf. The fault zone is linear exposing offset alluvial fans (west of Petra) and archeological features (Qasr Tilah); although the central part (about $30 \mathrm{~km}$ ) is concealed by sand dunes and may hide a main geometrical complexity, the fault section can be considered as a single fault segment and may be at the origin of a characteristic earthquake with $\mathrm{Mw} \geq 7.5$. Topography data is from SRTM (3-arc-second)

accumulation of sand dunes that conceals the fault zone around latitude $30^{\circ} \mathrm{N}$, the fault can be seen to affect successive stream channels and terraces. The northern half of the Wadi Araba fault exposes outstanding tectonic geomorphology with linear fault scarps showing offset alluvial fans and channels visible until the southeastern edge of the Dead Sea (Barjous and Mikbel 1990). The southern end of the DSF meets the Gulf of Aqaba that shows NNE-SSW trending relay fault system with large pull-apart basins in the sea bottom that may act as a geometrical barrier that limits the Wadi Araba fault zone to the south. Indeed, the Wadi Araba fault section is about 200-km long if we include the eastern edge of the Dead Sea area (Fig. 4), it may constitute a single fault segment or two distinct segments if a major geometrical complexity (relay zone) is hidden below the mid-distance sand dunes.

The Dead Sea area has the characteristics of a large pull-apart basin (100-km long, 17-km wide) limited by two north striking segments, the southern Wadi Araba fault zone and the northern Jordan valley fault segment. The latter segment follows the Jordan River, extends from the Dead Sea (right bank of the Jordan River) to the Tiberiade Lake and is made of a suite of 10-20-km-long subsegments (mostly on the left bank of the Jordan River) for a total length of $\sim 110 \mathrm{~km}$. In the valley, small pull-apart basins and restraining bends limit the subsegments and show left-lateral slip of stream channels (Fig. 5; Ferry 


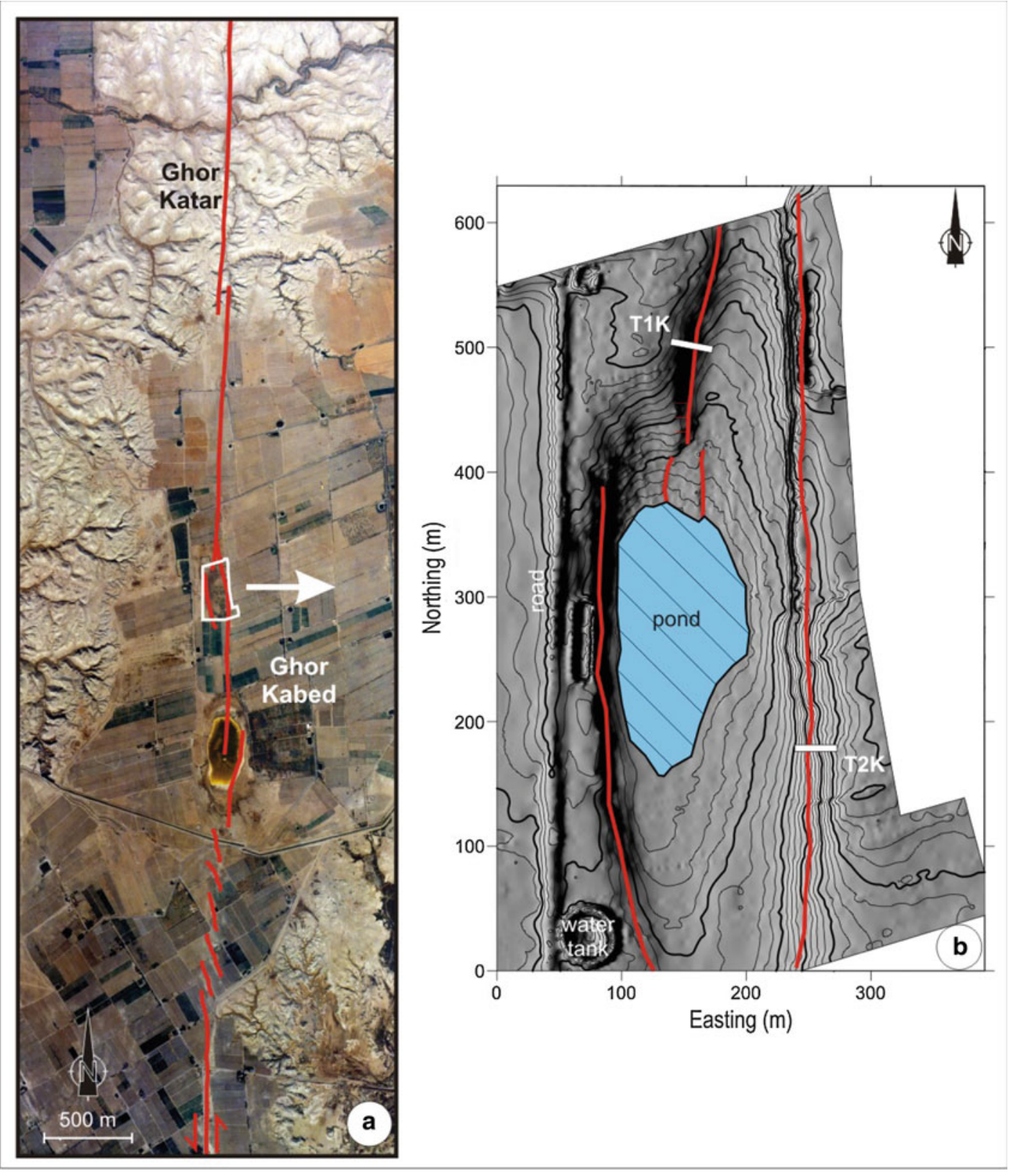

Fig. 5 (a) Aerial photograph of the Jordan valley fault (red lines) exposing small pull-apart basins with left-lateral en echelon fault structures and stream channel offsets (at Ghor Katar), (b) detail of the Ghor Kabed pull-apart basin with high-resolution topography and fault branches affecting the Lisan lacustrine deposits (see also trench sites TK1 and TK2 in Ferry et al. 2007)

et al. 2007). Although the Tiberiade Lake shows no pull-apart structure, it is located west of the fault and can be correlated further north to the Hula pull-apart (Heimann and Ron 1987).

The Lebanese restraining bend (LRB) is about 200-km-long positive flower structure, striking NE-SW, almost midway and on a right-stepping structure of the DSF (Fig. 3). Although the structure is made of four active fault branches, only the central Yammouneh fault is throughgoing and represents the main continuation of the DSF across the bend (Fig. 6; Gomez et al. 2003; Nemer et al. 2008). From the southern end of LRB, the westernmost Roum fault shows left-lateral strike-slip and vertical movements and is associated with fresh fault scarps and pressure ridges which attest for recent coseismic ruptures. To the northwest and from the northernmost end of the LRB, other southwest trending fault branches with 


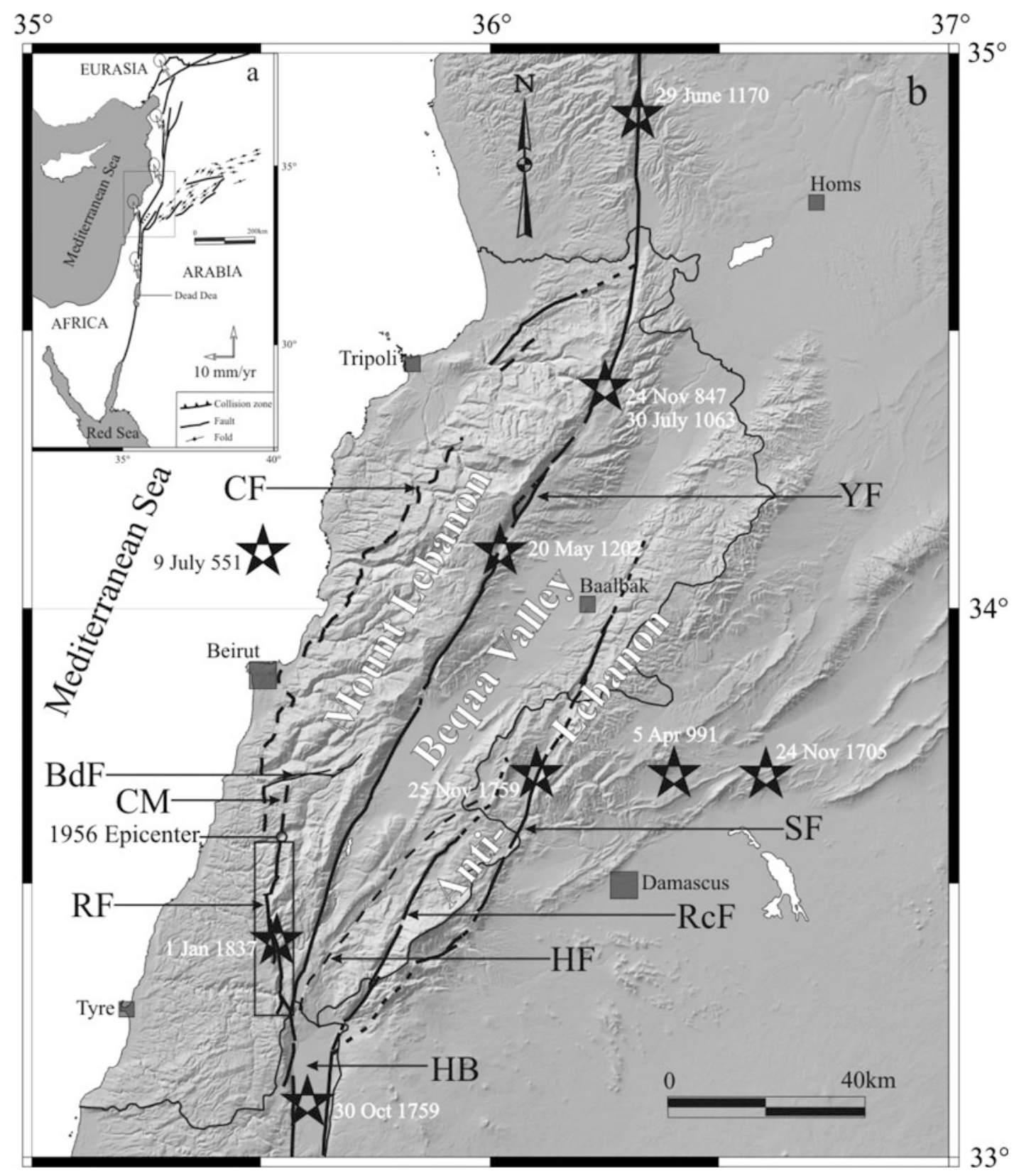

Fig. 6 Lebanon restraining bend with related fault branches and major earthquakes (stars) with $\mathrm{M}>6.5$ (Nemer et al. 2008). $Y F$ Yammouneh fault, $S F$ Serghaya fault, $R F$ Roum fault, $R c F$ Rachaya fault, $M Y$ Missyaf fault, $H B$ Hesbaya fault, $H B$ Hula basin, $C M$ Chouf mountains, and $C F$ Chouf fault. Main large historical earthquakes are indicated (star). Topography data is from SRTM (3-arc-second)

reverse geometry seem to extend offshore (Elias et al. 2007). The Rachaya and Serghaya faults are the easternmost fault branches showing left-lateral strike-slip movements associated with different geomorphic expressions of young surface ruptures (fault scarps, mole tracks, pressure ridges) and cumulative leftlateral slip on stream channels, alluvial fans, and small pull-apart basins. The LRB constitutes a large geometrical complexity as a result of the left-lateral block movements on the plate boundary.

The DSF northern section is made of two main north trending and linear segments that include the impressive Ghab pull-apart depression. From the LRB, the section begins with the Al Boqueia pull-apart structure (15-km long and 6-km wide) and extends with the $\sim 90-\mathrm{km}-$ long and linear Missyaf segment 


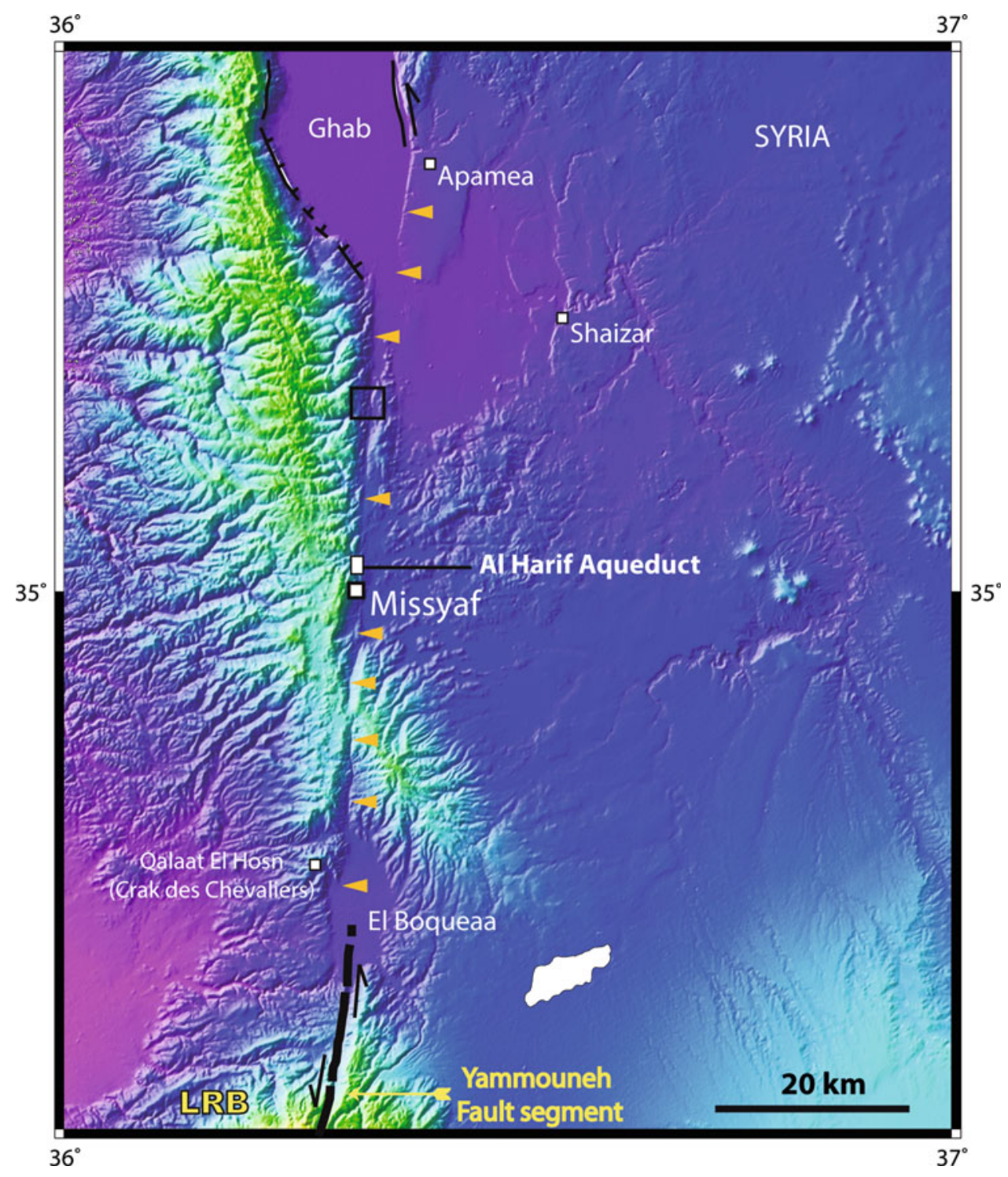

Fig. 7 Missyaf fault segment (yellow arrows) limited by the El Boquea and Ghab pull-apart basins, to the south and north, respectively (Meghraoui et al. 2003). Topography data is from SRTM (3-arc-second)

until the Ghab pull-apart (Fig. 7; Brew et al. 2001; Meghraoui et al. 2003). The Ghab depression is $15 \mathrm{~km}$ wide and is limited to the west by a $\sim 100-\mathrm{km}$-long fault segment that ends in the Amik basin and to the east by the continuation of the Missyaf segment. The northern area of the Ghab depression shows a partition between strike-slip faults and normal faulting, where the NE trending Antakya and Latakia strike-slip faults affect the western block and the Afrin fault "en echelon" system limits the eastern edge (Fig. 8; Gomez et al. 2007; Trifonov et al. 2012; Mahmoud et al. 2013). The northern end of the DSF and Ghab fault segments also shows left-lateral stream offsets, but the fault trace enters the Amik basin and becomes concealed below the young Quaternary sedimentation (Akyüz et al. 2006). The 200-km-long Missyaf and Ghab fault segments show different sizes of left-lateral stream offsets with shutter ridges and are probably responsible of the 2,000-m-high topographic offset of the western coastal range.

The occurrence of large earthquakes along the DSF closely depends on the extent of fault segments and the control of coseismic ruptures by the geometrical complexities. Large step overs and pull-apart basins (with width $>5 \mathrm{~km}$ ) and restraining bends may contribute to the arrest of earthquake ruptures and limit the 


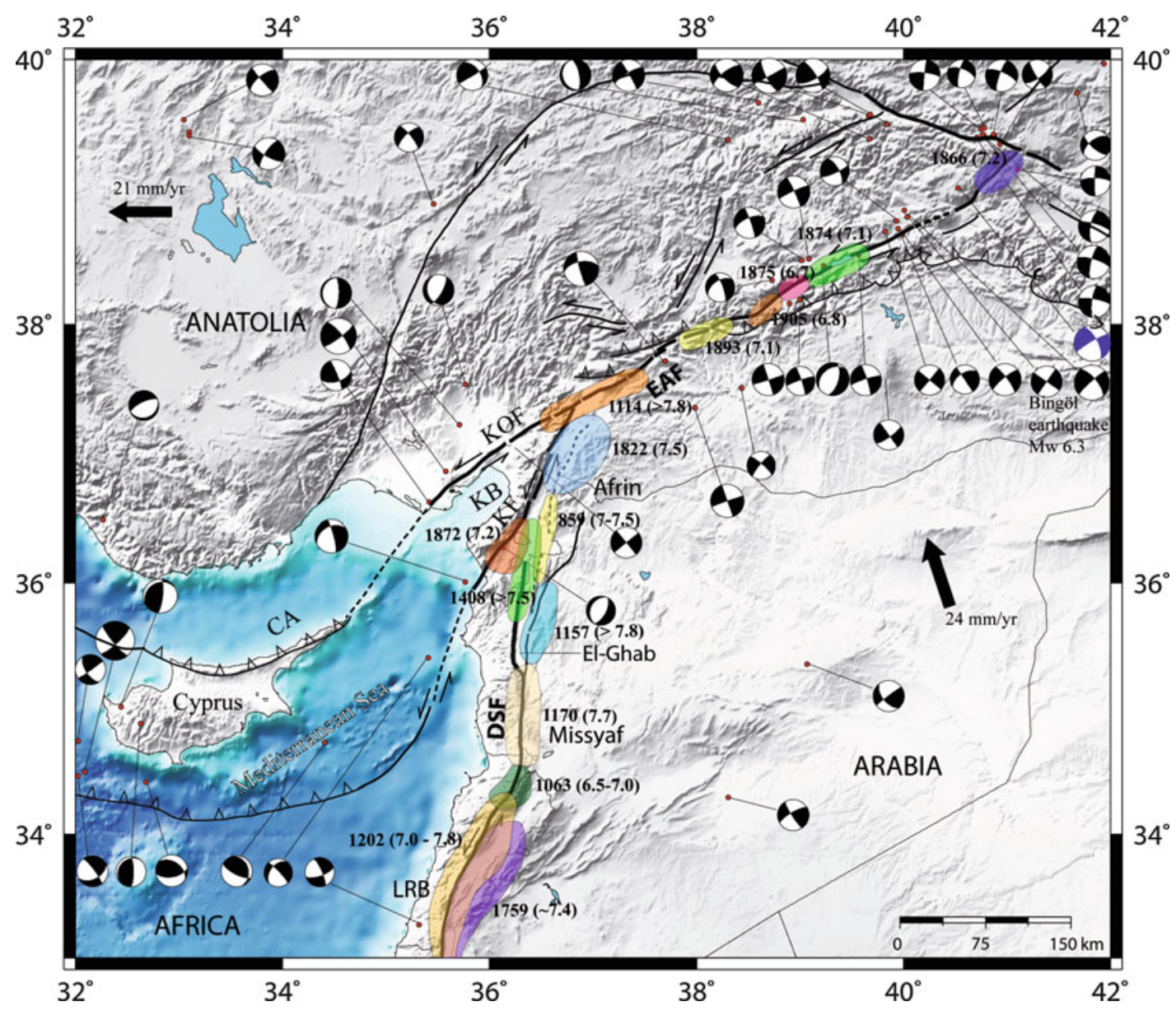

Fig. 8 Northern Dead Sea fault $(D S F)$ and its connection with the East Anatolian fault $(E A F)$ with the LRB and Missyaf-El Ghab segments, Afrin fault branch, Karasu fault $(K F)$, Karasu block $(K B)$, Karatas-Osmaniye fault $(K O F)$, and Cyprus Arc $(C A)$. Large historical earthquakes and their extent along fault segments are marked by colored areas (Sbeinati et al., 2005). The Arabian, Anatolian, and African plates mark the triple junction. Large arrows are plate velocities from GPS results, and focal mechanisms are from Harvard CMT solutions. Topography data is from SRTM (3-arc-second)

length of coseismic faults and, hence, the size of earthquakes (Wesnousky 2006). Main tectonic structures of the DSF such as the "en echelon" faults and basins of the Aqaba Gulf, the Dead Sea pull-apart basin, the Hula pull-apart basin, the LRB (although coseismic fault ruptures may occur with the restraining bend), the Ghab depression, and the Amik basin may act as major geometrical complexities and end points of large earthquakes $(\mathrm{Mw}>7)$.

\section{Large Earthquakes and Episodic Seismicity}

A unified parametric earthquake catalogue was compiled for the whole DSF and covering the period before 2000 (APAME 2007). The parametric catalogue is accompanied by a descriptive document which provides the macroseismic historical information and references which have been used for the compilation of the former (Sbeinati et al. 2005; Ambraseys 2009). For the pre-instrumental period, macroseismic data and a kriging technique were used to estimate macroseismic locations. In all, 1,000 earthquakes were identified and processed, to estimate position and uncertainty (Fig. 2). 


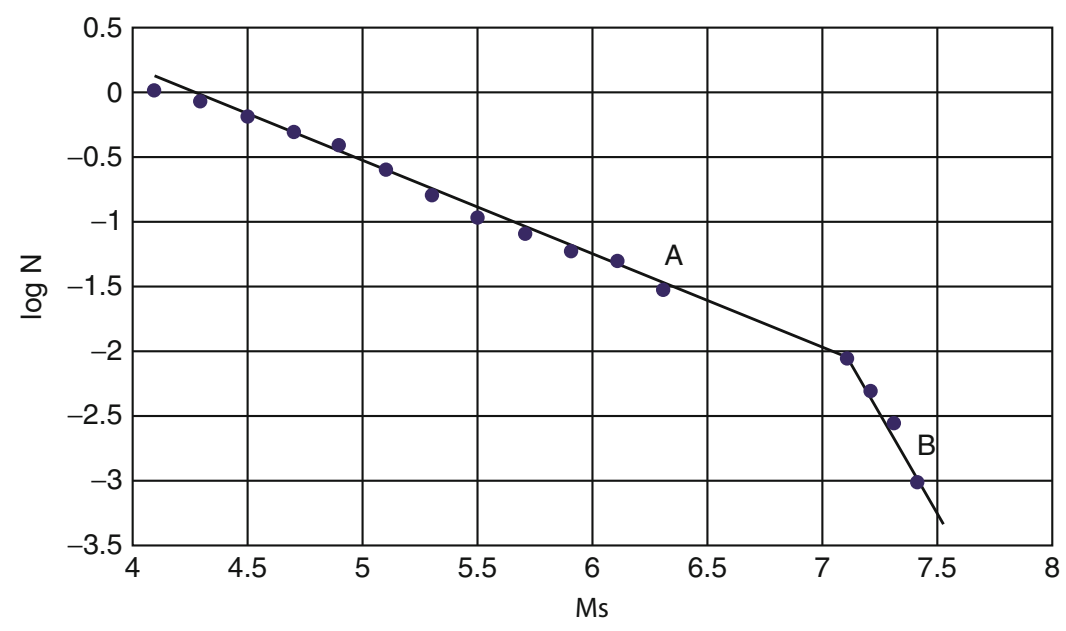

Fig. 9 Magnitude/frequency relation for the instrumental period $(A) \log N=3.02-0.73 M$, and the historical distribution $(B)$ follows $\log N=14.8-2.73 M(N$ is the number of earthquakes of a given magnitude $M$ or greater $)$ for the Dead Sea fault area (Elnashai and Al-Khoury 2004)

The catalogue shows that during the last century, seismic strain release of the DSF is curiously low with respect to that expected for a plate boundary. The instrumental seismicity shows the localized occurrence of shallow earthquakes (with a seismogenic layer $\leq 15-\mathrm{km}$ depth) with most local magnitude $\mathrm{M}_{\mathrm{L}}$ between 1 and 5.5 (Hofstetter et al. 2007; Bagh et al. 2014) and the largest event being the 11 July 1927, Ms 6.3 in the Dead Sea area. Focal mechanism solutions show mostly strike-slip faulting, but normal faulting mechanisms occur also in regions of pull-apart basins, while some thrust mechanisms appear in the LRB. The seismicity is not equally distributed along strike, and some fault segments such as the Missyaf and Jordan valley have seismic gaps (Fig. 2). Although taking place offshore in the Gulf of Aqaba, the 22 November 1995 seismic event reached Mw 7.3 and illustrates the north-south trending, left-lateral strike-slip mechanism with typical size of plate boundary earthquakes. Elnashai and El-Khoury (2004) combined the available instrumental and historical seismicity data of the continental DSF region to estimate the annual GR frequency-magnitude distribution. They found that for the instrumental seismicity, the frequency-magnitude distribution follows the relationship $\log N=3.02-0.73 \mathrm{M}$, while the historical distribution follows $\log N=14.8-2.73 M$ (Fig. 9). They noted that the seismicity of the last 100 years has been lower than expected to accommodate the Arabia-Africa relative motion.

The pre-instrumental seismicity and in particular large earthquakes of the prehistorical (archeological and antiquities) and historical period in the DSF region are well described. Earthquakes and their related severity of damage are reported by the different civilizations in wall inscriptions, manuscripts, poems, volumes of geographers, and mailed letters (Sbeinati et al. 2005; Finkbeiner et al. 2007; Ambraseys 2009). The oldest earthquake is reported in $~ 1365$ B.C. from the description of the destruction of Ugarit city in a letter sent by the governor Abilmiki of Tyre to the Pharaoh Amenophis IV (Akhenaton). The earthquakes of 31 B.C., 115 A.D., 363 A.D., and 526 A.D. are among the well reported during the Roman and Byzantine era; the latter is revealed by the monks following the destruction of the Saint Simeon monastery and nearby villages of northern Syria (also reported as the "legend of 1,000 lost villages" by historians). Large earthquakes reported in the medieval time (from eighth to sixteenth century) are among the well described, thanks to the Arab-Muslim civilization corroborated by the Crusader chroniclers. The earthquake of 1,202 estimated to be Ms 7.5 affected Lebanon where several km-long surface faulting is reported as crossing villages in mountains (Ambraseys 2009). Other large earthquakes such as 749 A.D., 859 A.D., 910 A.D., 1033 A.D., 1137 A.D., 1156 A.D., 1170 A.D., and 1268 A.D. (with M > 7) were responsible of severe damage. Their detailed description in manuscripts allows a correlation to fault 
segments without large uncertainties and ultimately to faulting events in paleoseismic and archeoseismic investigations.

\section{Paleo-archeo-earthquakes and the Rate of Slip}

First accounts of seismic structures in geological deposits reported in the Lisan lacustrine deposits of the Dead Sea describe continuous large earthquake sequences in the last $50 \mathrm{ka}$ (El-Isa and Mustafa 1986; Marco et al. 1996). Recent studies describing obvious faulting outcrops and clear accounts of historical earthquakes with surface ruptures generated a strong interest in the development of paleoseismic excavations along fault strike.

The richness of archeological sites along the DSF constitutes an exceptional advantage for dating prehistorical earthquakes. Field investigations revealed left-lateral faulting of the following archeological sites: a total of 2.1-m offset walls of a Crusader castle during the 20 May 1,202 and 30 October 1,759 earthquakes (Ellenblum et al. 1998); the cumulative 13.6-m offset of the Al Harif aqueduct since the Roman time, the most recent event being the 29 June 1,170 earthquake (Meghraoui et al. 2003); the 2.2-m offset wall of Qasr Tilah that can be related to an earthquake event in 608-826 A.D. (Klinger et al. 2000a); the offset Galei Kinneret city walls during the 18 January 749 earthquake (Marco et al. 2003); the minimum 1-m vertical slip of a qanat during the 1,068 earthquake on the southern DSF near Eilat (Zilberman et al. 2005); the cumulative offset of the Roman-Byzantine-Islamic Qasr Tilah site of the northern Araba valley during the 634 or $659 / 660,873,1,068$, and 1,546 earthquakes (APAME 2007); a total of $\sim 25 \mathrm{~m}$ of the $\sim 2000$ B.C. Tell Sicantarla, Hittite road, and Roman walls, with $\sim 9$-m offset during the 1,408 and 1,872 earthquakes (Altunel et al. 2009), and Tell Saidiyeh in 759 B.C., 1150 B.C., $\sim 2300$ B.C., and $\sim 2900$ B.C. (Jordan Valley, Ferry et al. 2011). These archeo-seismological studies of the DSF are complemented with tectonic geomorphology and paleoseismic investigations that constrain paleoearthquake faulting episodes and slip rates.

In trenches, radiocarbon dating brackets the 1,759 earthquake on the northern Jordan valley fault segment and the Serghaya fault branch through 3D trenching with 0.5 and $2.5-\mathrm{m}$ left-lateral slip, respectively (Gomez et al. 2003; Marco et al. 2005). The major 1,202 earthquake (Mw 7.6, Ambraseys and Jackson 1998) is bracketed in the northern Jordan valley at Beyt Zayda with 1.6-m left-lateral slip (Marco et al. 2005) and in the Lebanese segment of the DSF at the Yammouneh pull-apart basin (Fig. 7; Daëron et al. 2007; Nemer et al. 2008). Faulting of the 749 earthquake of the Jordan valley segment is resolved at Beyt Zayda (north of Tiberiade Lake) and Tell Saidiyeh (south Jordan valley) paleoseismic sites (Marco et al. 2005; Ferry et al. 2011). Paleoseismic trenches near the Al Harif aqueduct resolve three faulting events in 160-510 A.D., 625-690 A.D., and 1010-1210 A.D., the latter being correlated with the 1,170 large earthquake (Sbeinati et al. 2010). At the northern end of the DSF, faulting in trenches provides evidence for three historical earthquakes in 859, 1408, and 1872 A.D. (Akyüz et al. 2006). The longest paleoseismic records on the DSF are determined in the Jordan valley with a sequence of 12 coseismic surface ruptures over the last $14 \mathrm{ka}$ (Ferry et al. 2011) and 10-13 faulting events over the last $12 \mathrm{ka}$ on the Yammouneh fault of the DSF restraining bend in Lebanon (Daëron et al. 2007). Although the correlation with individual fault segments is problematic, another source of earthquake records in the Dead Sea lake sediments and speleothems indicates a succession of seismites synchronous to historical earthquakes in 1927, 1293, 1202/1212, 749, 551, 419, 33 A.D. and 31 B.C. and mid-second century B.C. (Marco et al. 1996; Kagan et al. 2011). From recent paleoseismic trenching, Klinger et al. (2015) identified faulting events along the southern DSF in the Wadi Araba, which can be correlated with past earthquakes in 1458, 1212, 1068, and 363 A.D., in addition of one faulting event bracketed between 806 A.D. and 1044 A.D., which can be correlated with the 972 earthquake. 


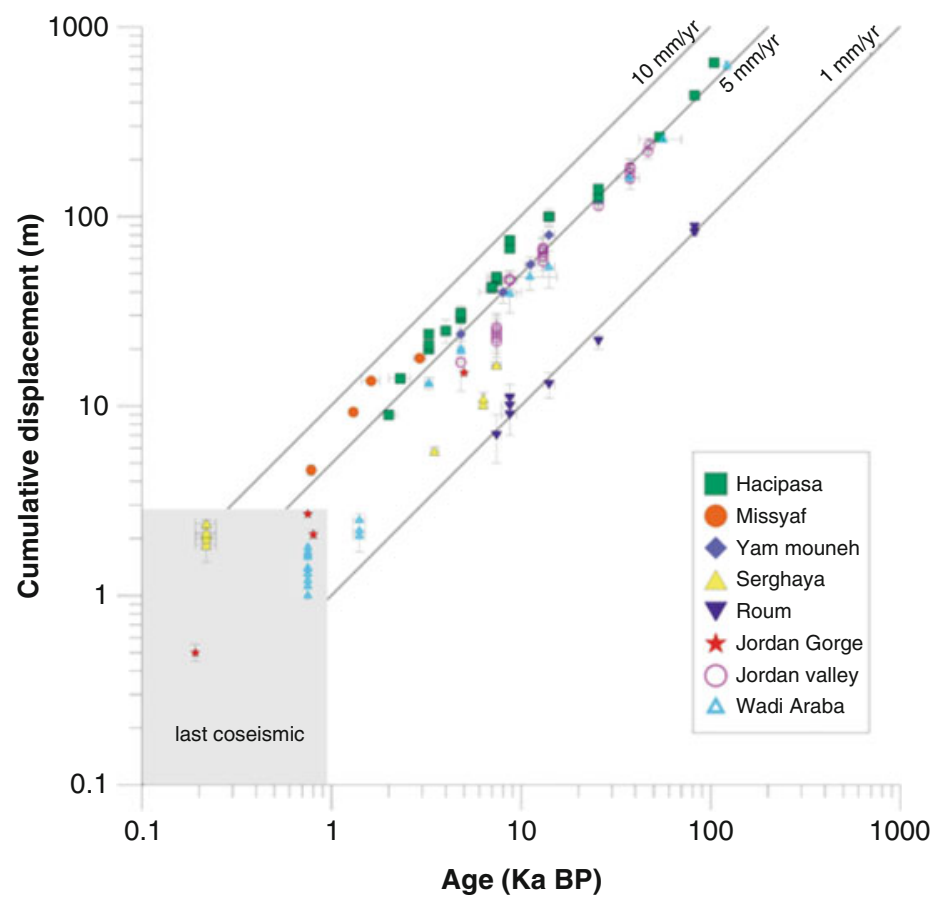

Fig. 10 Late Pleistocene-Holocene slip rate along the Dead Sea fault from different fault segments (compiled by Matthieu Ferry; see also Table 1): Hacipasa (Akyüz et al. 2006; Altunel et al. 2009), Missyaf (Meghraoui et al. 2003; Sbeinati et al. 2010), Yammouneh (Daeron et al. 2004; Nemer et al. 2008), Serghaya (Gomez et al. 2003), Roum (Nemer and Meghraoui 2006), Jordan Gorge (Marco et al. 2005), Jordan valley (Ferry et al. 2007), and Wadi Araba (Klinger et al. 2000b; Niemi et al. 2001; Le Beon et al. 2010)

Slip rate: The succession of large earthquakes is totally dependent on the rate of deformation and slip along the fault. Geologic and geomorphologic slip-rate estimates are mainly based on offset geomorphologic markers (e.g., stream channels, drainage basin, alluvial fans, terraces) and offset archeologic piercing points during an estimated time span that is usually determined using cosmogenic -isotopic dating. The characteristics of successive earthquake ruptures and coseismic displacement obtained from the geological and geomorphological offsets and paleoseismic studies on different fault segments provide access to the long-term seismogenic clock and average timing for the recurrence of large seismic events.

From earlier studies, the 107-km offset of 20 Myr dikes of Sinai and Jordan and 40-45-km offset upper Miocene formations provide 5.35-6.4-mm/year slip rate (Bartov et al. 1980; Garfunkel et al. 1981). Garfunkel et al. (1981) also estimate 5-10-mm/year seismic slip rate of the DSF based on the 8-km-offset Homs basalt north of the LRB during the Pleistocene and along the Yammouneh fault. Later on, Ginat et al. (1998) proposed a slip-rate range of 3-7.5 mm/year since late Pliocene/early Pleistocene. Using offset stream channels and alluvial fans along the Wadi Araba segment, Galli (1999) estimated 10-mm/ year slip rate of for the southern Wadi Araba and the southern Jordan valley for the last 50 and $18 \mathrm{kyr}$, respectively. Subsequent and more recent studies using more precise offset measurements (by means of total station and DGPS) and isotopic dating provide a better estimate of the long-term slip rate (Fig. 10; Table 1). Klinger et al. (2000b) suggested 2-6-mm/year slip rate over the late Pleistocene (77-140 kyr), and Niemi et al. (2001) proposed a slip-rate range of 3.4-6 mm/year for the last $15 \mathrm{kyr}$. This slip rate is in agreement with the $5.4 \pm 2.7 \mathrm{~mm} /$ year obtained from cosmogenic dating of paleosurfaces offset by the fault over the last $\sim 11 \mathrm{ka}$ in the southern Wadi Araba (Le Beon et al. 2010). In the Jordan valley, offset stream channels affecting the Lisan lacustrine deposits and archeological features yield $\sim 5 \mathrm{~mm} /$ year for the last $47.5 \mathrm{kyr}$ and $25 \mathrm{ka}$, respectively (Ferry et al. 2007; Ferry et al. 2011). North of the Sea of Galilee, at 
Table 1 Late Quaternary slip rate along the DSF

\begin{tabular}{|c|c|c|c|c|}
\hline Fault segment & Method & Time frame & $\begin{array}{l}\text { Slip rate } \\
(\mathrm{mm} / \text { year })\end{array}$ & References \\
\hline DSF & Geology & 15-20 Myr & $4-7$ & Quennell (1958) \\
\hline Wadi Araba & Geomorphology & $\begin{array}{l}\text { Late Pliocene/early } \\
\text { Pleistocene }\end{array}$ & $3-7.5$ & Ginat et al. (1998) \\
\hline Wadi Araba & Geomorphology & $141 \mathrm{kyr}$ & $\begin{array}{l}5.4 \pm 2.7 \\
4.5 \pm 0.9 \\
8.1 \pm 2.9\end{array}$ & Le Beon et al. (2010) \\
\hline Northern Wadi Araba & Geomorphology & $77-140 \mathrm{kyr}$ & $2-6$ & Klinger et al. (2000b) \\
\hline Northern Wadi Araba & Geomorphology & $15 \mathrm{kyr}$ & $3.4-6$ & Niemi et al. (2001) \\
\hline $\begin{array}{l}\text { Wadi Araba, Jordan } \\
\text { valley }\end{array}$ & Geomorphology & $\begin{array}{l}50 \mathrm{kyr} \\
18 \mathrm{kyr} \\
\end{array}$ & $\begin{array}{l}10 \\
10 \\
\end{array}$ & Galli (1999) \\
\hline $\begin{array}{l}\text { LRB (Yammouneh } \\
\text { fault) }\end{array}$ & Geomorphology & Pleistocene & $5-10$ & Garfunkel et al. (1981) \\
\hline $\begin{array}{l}\text { LRB (Yammouneh } \\
\text { fault) }\end{array}$ & Geomorphology & $25 \mathrm{kyr}$ & $3.8-6.4$ & Daeron et al. (2004) \\
\hline Roum fault & Paleoseismic & Holocene & $0.86-1.05$ & $\begin{array}{l}\text { Nemer and Meghraoui } \\
(2006)\end{array}$ \\
\hline DSTF & Seismicity & $1,000-1,500$ year & $1.5-3.5$ & Garfunkel et al. (1981) \\
\hline Wadi Araba & Geomorphology & Pleistocene & $4.7 \pm 1.3$ & Niemi et al. (2001) \\
\hline Wadi Araba & Geomorphology & Pleistocene & $2-6$ & Klinger et al. (2000b) \\
\hline Hula basin & Archeoseismic & 2,000 year & $>2.8 \pm 0.2$ & Agnon (2014) \\
\hline Jordan valley & Paleoseismic & Holocene & 2.5 & Marco et al. (2005) \\
\hline Jordan valley & Paleoseismic & 5,000 year & $\geq 3$ & Marco et al. (2005) \\
\hline Jordan valley & Geomorphology & $47.5 \mathrm{kyr}$ & $4.7-5.1$ & Ferry et al. (2007) \\
\hline Amik basin & $\begin{array}{l}\text { Geomorphology } \\
\text { Paleoseismic }\end{array}$ & Pleistocene & $4.94 \pm 0.13$ & Karabacak et al. (2010) \\
\hline Amik basin & Archeoseismic & $7 \mathrm{kyr}$ & 6 & Altunel et al. (2009) \\
\hline Missyaf & $\begin{array}{l}\text { Paleoseismic } \\
\text { Archeoseismic }\end{array}$ & 2,000 year & 6.9 & Meghraoui et al. (2003) \\
\hline Missyaf & $\begin{array}{l}\text { Paleo- } \\
\text { archeoseismic }\end{array}$ & 3,500 year & $4.9-6.3$ & Sbeinati et al. (2010) \\
\hline LRB (Serghaya fault) & Paleoseismic & Holocene & $1.4 \pm 0.2$ & Gomez et al. (2003) \\
\hline LRB & GPS & 4 year & 4.5 & Gomez et al. (2007) \\
\hline Northern DSF & GPS & 8 year & $1.8-3.3$ & Alchalbi et al. (2010) \\
\hline DSF triple junction & GPS & 3 year & $1-2$ & Mahmoud et al. (2013) \\
\hline DSF & GPS & 10 year & $4.4 \pm 0.3$ & Reilinger et al. (2006) \\
\hline Southern DSF & GPS & & $4.3-5.3$ & Al Tarazi et al. (2011) \\
\hline Southern DSF & GPS & 6 year & $4.9 \pm 1.4$ & Le Béon et al. (2008) \\
\hline Araba valley & GPS & 12 year & $4.7 \pm 0.7$ & Masson et al. (2015) \\
\hline Southern DSF & GPS & 7 year & $3.3 \pm 0.4$ & Wdowinski et al. (2004) \\
\hline
\end{tabular}

Beyt Zayda, Marco et al. (2005) estimate a minimum 3-mm/year slip rate from a paleoseismic study and 15-m-left-lateral offset stream channel during the last 5,000 years. Further north, the fault splays formed by the Yammouneh, Roum, Rachaya, and Serghaya faults revealed consistent slip rates across the LRB. The correlation of two 50-km-apart alluvial fan offsets along the Yammouneh fault by Daeron et al. (2004) yields $5.1 \pm 1.3-\mathrm{mm} /$ year slip rate during the late Pleistocene-Holocene. From stream offsets 
and paleoseismic trenching across the Roum fault, Nemer and Meghraoui (2006) estimate $0.86-1.05-\mathrm{mm} /$ year slip rate during the last 10,510 years. With the Rachaya and Serghaya faults being considered as pertaining to the same fault system, a $1.4 \pm 0.2-\mathrm{mm} /$ year slip rate during the Holocene is obtained from offset stream channels and paleoseismic studies (Gomez et al. 2003; Nemer et al. 2008). Further north, on the Missyaf fault segment, the 13.6-m offset Al Harif Roman aqueduct analyzed using paleoseismic and archeoseismic approach provides 4.9-6.3- $\mathrm{mm} /$ year slip rate during the last 4,300 years (Meghraoui et al. 2003; Sbeinati et al. 2010). Along with paleoseismic evidence of coseismic fault ruptures, the northern end of the DSF displays cumulative left-lateral offset stream channels and tells archeological feature, and yields an average 6.07- $\mathrm{mm} /$ year slip rate during the last $7 \mathrm{kyr}$ (Akyüz et al. 2006; Altunel et al. 2009; Karabacak et al. 2010).

\section{The Worrying Silence of a Major Continental Transform Fault}

In a recent past, the low-level instrumental seismicity and temporal seismic quiescence of the DSF erroneously suggested inactive faulting implying serious underestimation of the earthquake hazard in the Middle East. In contrast, large historical earthquakes $(\mathrm{Mw}>7)$ equally distributed along the entire fault length indicate the zones with seismic quiescence during the last centuries (Fig. 2). This distribution appears as not random, and the accuracy of historical seismicity catalogue (APAME 2007) combined with the fault-related geometrical complexities (see section "A Tectonic Fault Trace with Geometrical Complexities") and paleoseismic results (see also section "Paleo-archeo-earthquakes and the Rate of Slip") suggests long periods of quiescence primarily on individual fault segments (Fig. 11). In fact, the long-term rate of active faulting and long record of past earthquakes, compared to the geodetic rate of active deformation (GPS velocity rate), point toward the level of a significant seismic coupling on the Jordan valley and Missyaf rupture segments of the DSF (Meghraoui et al. 2015).

A seismic slip deficit can be estimated from the comparison between the geodetic rate (deep off-fault deformation) and fault slip rate taking into account the DSF segmentation, fault segment length, maximum size of historical earthquakes, and inferred coseismic slip distribution (from paleoseismology and archeoseismology). The left-lateral slip obtained from the geodetic rate or tectonic rate of deformation (Meghraoui et al. 2003; Marco et al. 2005; Ferry et al. 2007; Alchalbi et al. 2010; Al Tarazi et al. 2011), compared to the seismic quiescence for large earthquakes in the last 1,000 years or so, implies $\sim 4.5$-m slip deficit which corresponds to the occurrence of a Mw 7.4-7.5 along the fault. The interseismic time reaches $952 \pm 115$ years and $761 \pm 150$ years for Mw 7.5-7.4 on the Jordan valley and Missyaf fault segments, respectively (Table 2; Meghraoui et al. 2015).

The identification of seismic gaps with temporal quiescence reaching 982 and 845 years (as per the year 2015) on the Jordan valley and Missyaf fault segments, respectively, calls for an urgent earthquake hazard evaluation and related risk mitigation, especially in major urban areas. If the interevent times proposed by Meghraoui et al. (2015) are valid for other DSF segments as the Ghab and LRB, the occurrence of large seismic events with M $>7$ in 1,408 and 1759-1837 (Fig. 11; APAME 2007; Ambraseys 2009) suggests a relatively low seismic risk for these regions. An uncertainty remains, however, for the Wadi Araba fault segments where the location and size of past earthquakes are poorly known. Although archeoseismic and geomorphic studies of paleoearthquake markers document faulting events (Galli 1999; Klinger et al. 2000a; Zilberman et al. 2005; Le Beon et al. 2010; klinger et al. 2015), the 200-km-long and linear fault zone in the desert still needs more paleoseismic studies, especially because historical seismicity data is very limited and the correlation between past large earthquakes from catalogue (e.g., the 365 earthquake that destroyed Petra; Ambraseys 2009) and faulting events is not straightforward. 


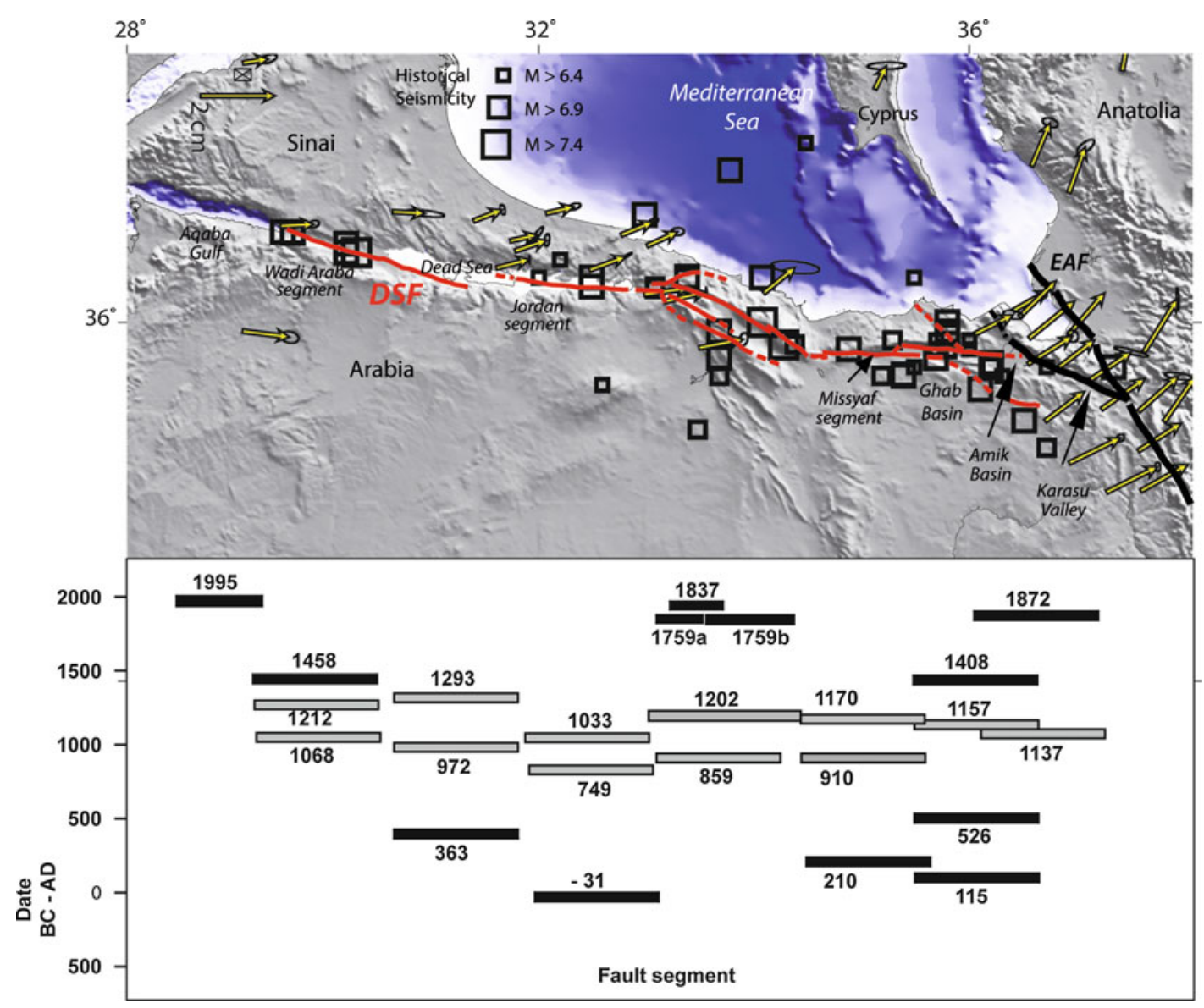

Fig. 11 Historical large earthquakes $(M>6.4)$ correlated with each fault segment according to the detailed study of earthquake damage area along the Dead Sea fault (Guidoboni et al. 1994; Ambraseys and Jackson 1998; Sbeinati et al. 2005; Zilberman et al. 2005; APAME 2007; Finkbeiner et al. 2007; Ambraseys 2009). Gray segments belong to a Middle Age earthquake sequence and southward migration along the fault. GPS velocities are obtained with Eurasia-fixed reference frame (Reilinger et al. 2006), and background topography/bathymetry is from GEBCO

Table 2 Fault parameters of the Jordan valley and Missyaf fault segments with slip rate and time interval $T_{i}$

\begin{tabular}{l|l|l|l|l|l|l|l}
\hline Fault & $\begin{array}{l}\text { Length } \\
(\mathrm{km})\end{array}$ & $\begin{array}{l}\text { Width } \\
(\mathrm{km})\end{array}$ & Slip $(\mathrm{m})$ & $\begin{array}{l}\text { Seismic moment } \\
(\mathrm{N} . \mathrm{m} .)\end{array}$ & $\begin{array}{l}\text { Geodetic rate } \\
(\mathrm{mm} / \text { year})\end{array}$ & $\begin{array}{l}\text { Slip rate } \\
(\mathrm{mm} / \text { year })\end{array}$ & $\mathrm{T}_{\mathrm{i}}(\mathrm{year})$ \\
\hline $\begin{array}{l}\text { Jordan } \\
\text { valley }\end{array}$ & 110 & 12 & $4.5 \pm 1.5$ & $2.010^{20}$ & 5 & 4.9 & $\begin{array}{l}\mathrm{T}=952 \pm \\
115\end{array}$ \\
\hline $\begin{array}{l}\text { Missyaf } \\
\text { segment }\end{array}$ & 90 & 12 & $4.5 \pm 0.3$ & $1.610^{20}$ & 3 & 5.9 & $\begin{array}{l}\mathrm{T}=761 \pm \\
150\end{array}$ \\
\hline
\end{tabular}

An attempt at seismic hazard evaluations including earthquake geology and paleoseismic data is provided for the northern DSF in Syria and Lebanon and in northern Araba valley and the Jordan valley segment (Al-Tarazi and Sandvol 2007). Preliminary results that include earthquake faulting parameters and paleoseismic data suggest a high level of hazard and risk along the DSF and on the Jordan valley and Missyaf fault segments in particular, where the peak ground acceleration (PGA) may reach $0.8 \mathrm{~g}$. For the long-term, 2,000-year-long period of observations, it is found that the frequency-magnitude distribution 
along the DSFZ is not only strongly nonlinear but also that seismicity is clustered in time (APAME 2007; Salamon 2010; Sbeinati et al. 2010).

\title{
Cross-references
}

\author{
- Archaeoseismology \\ - Earthquake Mechanisms and Tectonics \\ - Earthquake Recurrence \\ $\checkmark$ Paleoseismic History of the North Anatolian Fault Zone \\ - Paleoseismic History of the San Andreas Fault Zone \\ - Paleoseismic Trenching \\ > Paleoseismology \\ Seismic Hazard Characterization
}

\section{References}

Abou Romieh M, Westaway R, Daoud M, Radwan Y, Yassminh R, Khalil A, Al- Ashkar A, Loughlin S, Arrell K, Bridgland D (2009) Active crustal shortening in NE Syria revealed by deformed terraces of the River Euphrates. Terra Nova 21(6):427-437. doi:10.1111/j.1365-3121.2009.00896.x

Agnon A (2014) Pre-instrumental earthquakes along the Dead Sea Rift. In: Garfunkel Z et al (eds) Dead Sea transform fault system: reviews, vol 6, Modern approaches in solid earth sciences. Springer, Dordrecht, p 207. doi:10.1007/978-94-017-8872-4_8

Akyüz H, Altunel E, Karabacak V, Yalciner C (2006) Historical earthquake activity of the northern part of the Dead Sea fault zone, southern Turkey. Tectonophysics 426:281-293

Alchalbi A et al (2010) Crustal deformation in northwestern Arabia from GPS measurements in Syria: slow slip rate along the northern Dead Sea fault. Geophys J Int 180:125-135. doi:10.1111/j.1365246X.2009.04431.x

Al Tarazi E, Abu Rajab J, Gomez F, Cochran W, Jaafar R, Ferry M (2011) GPS measurements of nearfield deformation along the southern Dead Sea fault system, G-cubed 12. Geochem Geophys Geosyst 12(12):Q12021. doi:10.1029/2011GC003736

Al-Tarazi E, Sandvol E (2007) Alternative models of seismic hazard evaluation along the Jordan Dead Sea transform. Earthquake Spectra 23(1):1-19

Altunel E, Meghraoui M, Karabacak V, Akyüz S, Ferry M, Yalçiner Ç, Munschy M (2009) Archaeological sites (Tell and Road) offset by the Dead Sea fault in the Amik Basin, Southern Turkey. Geophys J Int 179:1313-1329

Ambraseys NN (2009) Earthquakes in the Mediterranean and Middle East: a multidisciplinary study of seismicity up to 1900. Cambridge University Press, Cambridge, MA, $947 \mathrm{p}$

Ambraseys N, Barazangi M (1989) The 1759 earthquake in the Bekaa valley: implications for earthquake hazard assessment in the eastern Mediterranean region. J Geophys Res 94:4007-4013

Ambraseys NN, Jackson JA (1998) Faulting associated with historical and recent earthquakes in the Eastern Mediterranean region. Geophys J Int 133(2):390-406

Amiran D, Arieh E, Turcotte T (1994) Earthquakes in Israel and adjacent areas: macroseismic observations since 100 BCE. Isr Expl J 44:260-305

APAME (2007) Archeoseismology and paleoseismology for the protection of cultural heritage and archeological sites in the Middle East: the impact of large earthquakes on the archaeological sites 
and cultural heritage in the Middle East (Jordan, Lebanon, Syria and Turkey, APAME EC project - ICA-CT-2002-10024 - Coordinator Mustapha Meghraoui, DG XII Brussels

Bagh S, Alhasan A, Tello S (2014) Local magnitude calibration of the syrian national digital seismological network. Seismol Res Lett 85:324-333. doi:10.1785/0220130021

Barjous M, Mikbel S (1990) Tectonic evolution of the Gulf of Aqaba - Dead Sea transform fault system. Tectonophysics 180:49-59

Bartov Y, Steinitz G, Eyal M, Eyal Y (1980) Sinistral movement along the Gulf of Aqaba - its age and relation to the opening of the Red Sea. Nature 285:220-221

Brew G, Lupa J, Barazangi M, Sawaf T, Al Imam A, Zaza T (2001) Tectonic and geological evolution of Syria. J Geol Soc Lond 158:665-674

Chaimov TA, Barazangi M, Al-Saad D, Sawaf T, Gebran A (1990) Crustal shortening in the Palmyride fold belt, Syria, and implications for movement along the Dead Sea fault system. Tectonics 9:1369-1386

Daeron M, Benedetti L, Tapponnier P, Sursock A, Finkel RC (2004) Constraints on the post-25-ka slip rate of the Yammouneh fault (Lebanon) using in situ cosmogenic Cl-36 dating of offset limestone-clast fans. Earth Planet Sci Lett 227:105-119

Daëron M, Klinger Y, Tapponnier P, Elias A, Jacques E, Sursock A (2007) 12,000-year-long record of 10 to 13 paleo-earthquakes on the Yammouneh fault (Levant fault system, Lebanon). Bull Seismol Soc Am 97(3):749-771

Dubertret L (1932) Les formes structurales de la Syrie et de la Palestine. CR Hebd Séances Acad Sci Paris 195:9-20

El-Isa ZH, Mustafa H (1986) Earthquake deformations in the Lisan deposits and seismotectonic implications. Geophys J R Astron Soc 86:413-424

Elias A, Tapponnier P, Singh SC, King GCP, Briais A, Daëron M, Carton H, Sursock A, Jacques E, Jomaa R, Klinger Y (2007) Active thrusting offshore Mount Lebanon: source of the tsunamigenic A.D. 551 Beirut-Tripoli earthquake. Geology 35:755-758

Ellenblum R, Marco S, Agnon A, Rockwell T, Boas A (1998) Crusader castle torn apart by earthquake at dawn, 20 May 1202. Geology 26:303-306

Elnashai AS, El-Khoury R (2004) Earthquake hazard in Lebanon. Imperial College Press, London/River Edge, $171 \mathrm{p}$

Ferry M, Meghraoui M, AbouKaraki N, Al-Taj M, Amoush H, Al-Dhaisat S, Barjous M (2007) A 48-kyr-long slip rate history for the Jordan Valley segment of the Dead Sea fault, Earth Planet. Sci Lett 260:394-406

Ferry M, Meghraoui M, Abou Karaki N, Al-Taj M, Khalil L (2011) Episodic behavior of the Jordan Valley section of the Dead Sea fault from a 14-kyr-long integrated catalogue of large earthquakes. Bull Seismol Soc Am 101(1):39-67. doi:10.1785/0120100097

Finkbeiner et al (2007) Catalogue of damage distribution due to historical earthquakes in the Middle East, APAME EC project - ICA-CT-2002-10024 - DG XII Brussels

Galli P (1999) Active tectonics along the Wadi Araba-Jordan Valley transform fault. J Geophys Res B [Solid Earth Planets] 104:2777-2796

Garfunkel Z, Zak I, Freund R (1981) Active faulting in the Dead Sea rift. Tectonophysics 80:1-26

Ginat H, Enzel Y, Avni Y (1998) Translocated Plio-Pleistocene drainage systems along the Arava fault of the Dead Sea transform. Tectonophysics 284:151-160. doi:10.1016/S0040-1951(97)00165-0

Gomez F, Meghraoui M, Darkal AN, Hijazi F, Mouty M, Suleiman Y, Sbeinati R, Darawcheh R, Al-Ghazzi R, Barazangi M (2003) Holocene faulting and earthquake recurrence along the Serghaya branch of the Dead Sea fault system in Syria and Lebanon. Geophys J Int 153:658-674 
Gomez F, Karam G, Khawlie M, McClusky S, Vernant P, Reilinger R, Jaafar R, Tabet C, Khair K, Barazangi M (2007) Global positioning system measurements of strain accumulation and slip transfer through the restraining bend along the Dead Sea fault system in Lebanon. Geophys J Int 168:1021-1028

Guidoboni E, Comastri A, Traina G (1994) Catalogue of ancient earthquakes in the Mediterranean area up to the 10th century. ING Roma-SGA, Bologna, $504 \mathrm{pp}$

Heimann A, Ron H (1987) Young faults in the Hula pull-apart basin, central Dead Sea transform. Tectonophysics 141:117-124

Hofstetter R, Klinger Y, Amrat AQ, Rivera L, Dorbath L (2007) Stress tensor and focal mechanisms along the Dead Sea fault and related structural elements based on seismological data. Tectonophysics 429(3-4):165-181

Kagan E, Stein M, Agnon A, Neumann F (2011) Intrabasin paleoearthquake and quiescence correlation of the late Holocene Dead Sea. J Geophys Res 116(B4). doi:10.1029/2010JB007452

Karabacak V, Altunel E, Meghraoui M, Akyüz HS (2010) Field evidences from northern Dead Sea Fault Zone (South Turkey): new findings for the initiation age and slip rate. Tectonophysics 480(1 4):172-182

Klinger Y, Avouac JP, Dorbath L, Abou Karaki N, Tisnerat N (2000a) Seismic behaviour of the Dead Sea fault along Araba valley, Jordan. Geophys J Int 142:769-782. doi:10.1046/j.1365-246x.2000.00166.x

Klinger Y, Avouac J-P, AbouKaraki N, Dorbath L, Bourles D, Reyss JL (2000b) Slip rate on the Dead Sea transform in northern Araba valley (Jordan). Geophys J Int 142:755-768

Klinger Y, Le Béon M, Al-Qaryouti M (2015) 5000 yr of paleoseismicity along the southern Dead Sea fault. Geophys J Int 202:313-327

Le Béon M, Klinger Y, Amrat AQ, Agnon A, Dorbath L, Baer G, Ruegg JC, Charade O, Mayyas O (2008) Slip rate and locking depth from GPS profiles across the southern Dead Sea Transform. J Geophys Res 113:1-19

Le Beon M, Klinger Y, Al-Qaryouti M, Meriaux AS, Finkel RC, Elias A, Mayyas O, Ryerson FJ, Tapponnier P (2010) Early Holocene and Late Pleistocene slip rates of the southern Dead Sea fault determined from Be-10 cosmogenic dating of offset alluvial deposits. J Geophys Res Solid Earth 115(B11414):24

Mahmoud Y, Masson F, Meghraoui M, Cakir Z, Alchalbi A, Yavasoglu H, Yönlü O, Daoud M, Ergintav S, Inan S (2013) Kinematic study at the junction of the East Anatolian fault and the Dead Sea fault from GPS measurements. J Geodyn 67:30-39. doi:10.1016/j.jog.2012.05.006

Marco S, Stein M, Agnon A, Ron H (1996) Long-term earthquake clustering: a 50,000-year paleoseismic record in the Dead Sea Graben. J Geophys Res 101:6179-6191

Marco S, Hartal M, Hazan N, Lev L, Stein M (2003) Archaeology, history, and geology of the A.D. 749 earthquake, Dead Sea transform. Geology 31:665-668

Marco S, Rockwell T, Heimann A, Frieslander U (2005) Late Holocene activity of the Dead Sea transform revealed in 3D paleoseismic trenches on the Jordan Gorge segment, Earth Planet. Sci Lett 234:189-205

Masson F et al (2015) Variable behavior of the Dead Sea Fault along the southern Araba segment from GPS measurements. Compet Rendus Geosci. doi:10.1016/j.crte.2014.11.001 (in press)

McCalpin JP (ed) (1996) Paleoseismology: San Diego. Academic, California, 588 p

Meghraoui M et al (2003) Evidence for 830 years of seismic quiescence from palaeoseismology, archaeoseismology and historical seismicity along the Dead Sea fault in Syria, Earth Planet. Sci Lett 210:35-52

Meghraoui MR, Toussaint MF, Nguema-Edzang P (2015) Slip deficit and location of seismic gaps along the Dead Sea fault, Geophysical research abstracts, vol 17, EGU2015-5218. EGU General Assembly, Vienna 
Nemer T, Meghraoui M (2006) Evidence of coseismic ruptures along the Roum fault (Lebanon): a possible source for the AD 1837 earthquake. J Struct Geol 28:1483-1495

Nemer T, Gomez F, Al Haddad S, Tabet C (2008) Coseismic growth of sedimentary basins along the Yammouneh strike-slip fault (Lebanon). Geophys J Int 175:1023-1039

Niemi TM, Zhang H, Atallah M, Harrison JBJ (2001) Late Pleistocene and Holocene slip rate of the Northern Wadi Araba fault, Dead Sea Transform, Jordan. J Seismol 5:449-474

Palano M, Paola Imprescia P, Gresta S (2013) Current stress and strain-rate fields across the Dead Sea fault system: constraints from seismological data and GPS observations. Earth Planet Sci Lett 369-370(2013):305-316

Quennell AM (1958) The structural and geomorphic evolution of the Dead Sea rift. Q J Geol Soc Lond 114:1-24

Reilinger R et al (2006) GPS constraints on continental deformation in the Africa-Arabia-Eurasia continental collision zone and implications for the dynamics of plate interactions. J Geophys Res 111:B05411. doi:10.1029/2005JB004051

Salamon A (2010) Patterns of seismic sequences in the Levant - interpretation of historical seismicity. J Seismol 14:339-367. doi:10.1007/s10950-009-9168-9

Sbeinati MR, Darawcheh R, Mouty M (2005) The historical earthquakes of Syria: an analysis of large seismic events from 1365 B.C. to1900 A.D. Ann Geophys 48:347-435

Sbeinati MR, Meghraoui M, Suleyman G, Gomez F, Grootes P, Nadeau M, Al Najjar H, Al-Ghazzi R (2010) Timing of earthquake ruptures at the Al Harif Roman Aqueduct (Dead Sea fault, Syria) from archeoseismology and paleoseismology, Special volume "Archaeoseismology and paleoseismology. In: Sintubin M, Stewart IS, Niemi TM, Altunel E (eds) Ancient earthquakes: geological society of America special paper, 471. doi:10.1130/2010.2471(20)

Sieh K (1996) The repetition of large-earthquake ruptures. Proc Natl Acad Sci 93:3764-3771

Trifonov et al (2012) Neotectonics, recent geodynamics and seismic hazard of Syria. In: Transactions of the geological institute, vol 598. GEOS, Moscow, 204 pp

Wdowinski SS, Bock YY, Baer GG, Prawirodirdjo LL, Bechor NN, Naaman SS, Melzer YY (2004) GPS measurements of current crustal movements along the Dead Sea Fault. J Geophys Res 109(B5). doi:10.1029/2003JB002640

Weber M et al (2009) Anatomy of the Dead Sea transform from lithospheric to microscopic scale. Rev Geophy 47:RG2002. doi:10.1029/2008RG000264

Wesnousky SG (2006) Predicting the endpoints of earthquake ruptures. Nature 444(7117):358-360

Yeats RS, Sieh K, Allen CR (1997) The geology of earthquakes. Oxford University Press, New York, $568 \mathrm{pp}$

Zilberman E, Amit R, Porat N, Enzel Y, Avner U (2005) Surface ruptures induced by the devastating 1068 A.D. earthquake in the southern Arava valley, Dead Sea Rift, Israel. Tectonophysics 408:79-99 